\title{
MECHANICAL CHARACTERIZATION OF ANCIENT PORTUGUESE RIVETED BRIDGES STEELS
}

\author{
Patrícia RAPOSO ${ }^{\mathrm{a}, \mathrm{b}}$, José CORREIA ${ }^{\mathrm{a}, \mathrm{b}}$, Grzegorz LESIUK ${ }^{\mathrm{c}}$, \\ Isabel VALENTE ${ }^{\mathrm{d}}$, Abílio DE JESUS ${ }^{\mathrm{a}, \mathrm{b}}$, Rui CALÇADA ${ }^{\mathrm{a}}$ \\ ${ }^{a}$ Faculty of Engineering, University of Porto, Rua Dr. Roberto Frias, \\ Campus FEUP, 4200-465 Porto, Portugal \\ ${ }^{b}$ INEGI, University of Porto, Rua Dr. Roberto Frias, Campus FEUP 400, 4200-465 Porto, Portugal \\ ${ }^{c}$ Mechanics department, Wroclaw University of Science and Technology, \\ Smoluchowskiego st., 25, Wrocław, 50-370, Poland \\ ${ }^{d}$ Engineering School, University of Minho, Campus de Azurém, 4800-058 Guimarães, Portugal
}

Received 07 November 2017; accepted 05 December 2017

\begin{abstract}
In repairing and retrofitting processes of ancient riveted steel bridges is crucial to assess the structural state of old metals to guaranty structural safety. Metals under long-time operations (mild, rimmed low carbon steels $<0.1 \% C$, puddle irons) and cyclic loading present a tendency for degradation processes. The case-studies of this work are five metallic bridges existing in Portugal (Luiz I, Eiffel, Fão, Pinhão and Trezói). This work presents the study of some characteristics of materials extracted from the five case-studies, such as: monotonic tensile strength, chemical composition, microstructures, hardness, notch toughness and fatigue crack propagation. In terms of monotonic tensile tests, the materials from Luiz I, Eiffel and Fão bridges are similar to puddle steel and the materials from Pinhão and Trezói bridges are similar to mild steel. In terms of toughness only the material from the Pinhão bridge exhibits acceptable toughness properties, considering current design requirements. The materials from the other bridges exhibit relatively low toughness properties. The fatigue crack propagation data from the old Portuguese riveted steel bridges were correlated using the Paris's law and the possibility for a design crack growth rate was discussed.
\end{abstract}

Keywords: monotonic tests, microstructure, chemical characterization, notch toughness, fracture mechanics.

\section{Introduction}

A great concern of the governmental agencies is the maintenance and safety of existing bridges, in particular, highway and railway riveted bridges from the end of the $19^{\text {th }}$ century and beginning of the $20^{\text {th }}$ century, since they were designed for completely different traffic conditions, in terms of vehicles loads and frequen$\mathrm{cy}$, that the ones they are under nowadays, leading to problems such as fatigue (De Jesus et al. 2014b, 2014a; Sanches et al. 2015). The governmental entities are responsible for maintaining and retrofitting those kind of structures to assure high safety levels, requiring high investments (Fernandes et al. 2004; Figueiredo et al. 2004, 2006; Jorge et al. 2006; Correia et al. 2008a, 2008b; De Jesus et al. 2011).

The correct maintenance and retrofitting of old steel structures requires the use of adequate diagnostic and evaluation tools and methods leading to cheaper and secure solutions, following the normative regulations of modern structures (Shinae et al. 2013; Lesiuk et al. 2015; Ohga et al. 2010; De Jesus et al. 2010).

Corresponding author:

P. Raposo E-mail: praposo@inegi.up.pt 
The steels of old structures exhibit a tendency for microstructure degradation processes (Lesiuk 2013). According to the Linear Elastic Fracture Mechanics (LEFM) the crack propagation data is essential to predict about fatigue life (Correia et al. 2008b). This is an important alternative to the usual code based S-N curve procedures, especially regarding to residual life estimations (Correia et al. 2008b). The knowledge about the variability analysis of fatigue crack growth rates is very important since the LEFM requires the definition of an initial crack, this is previous fatigue damage (Correia et al. 2008b).

This works aims to present a review of the old steels mechanical characterization, including monotonic tensile strength, chemical composition, microstructures, hardness, notch toughness and crack prop- agation. The case-study bridges are: Luiz I (Fig. 1a), Eiffel bridge (Fig. 1 b), Fão (Fig. 1c), Pinhão (Fig. 1d) and Trezói (Fig. 1e).

Luiz I bridge (Figure 1 (a)), designed by Théophile Seyrig, binds the cities of Porto and Gaia. The bridge serves both highway and railway traffic and was finished in 1886 (Correia et al. 2008b). The bridge has a double deck supported by an arch, with a radius of $45 \mathrm{~m}$, a span of $172 \mathrm{~m}$ and a width of $8 \mathrm{~m}$ (the original width was $6 \mathrm{~m}$ ) (Correia et al. 2008b). The length of the upper deck is $391.25 \mathrm{~m}$ and the length of the lower deck is $174 \mathrm{~m}$. The Eiffel bridge (Fig. 1b), was designed by Gustave Eiffel and inaugurated in 1878 . This bridge bonds Darque and Viana do Castelo, and serves highway and railway traffic. The bridge has a length of $573 \mathrm{~m}$, split in nine spans, and a width of
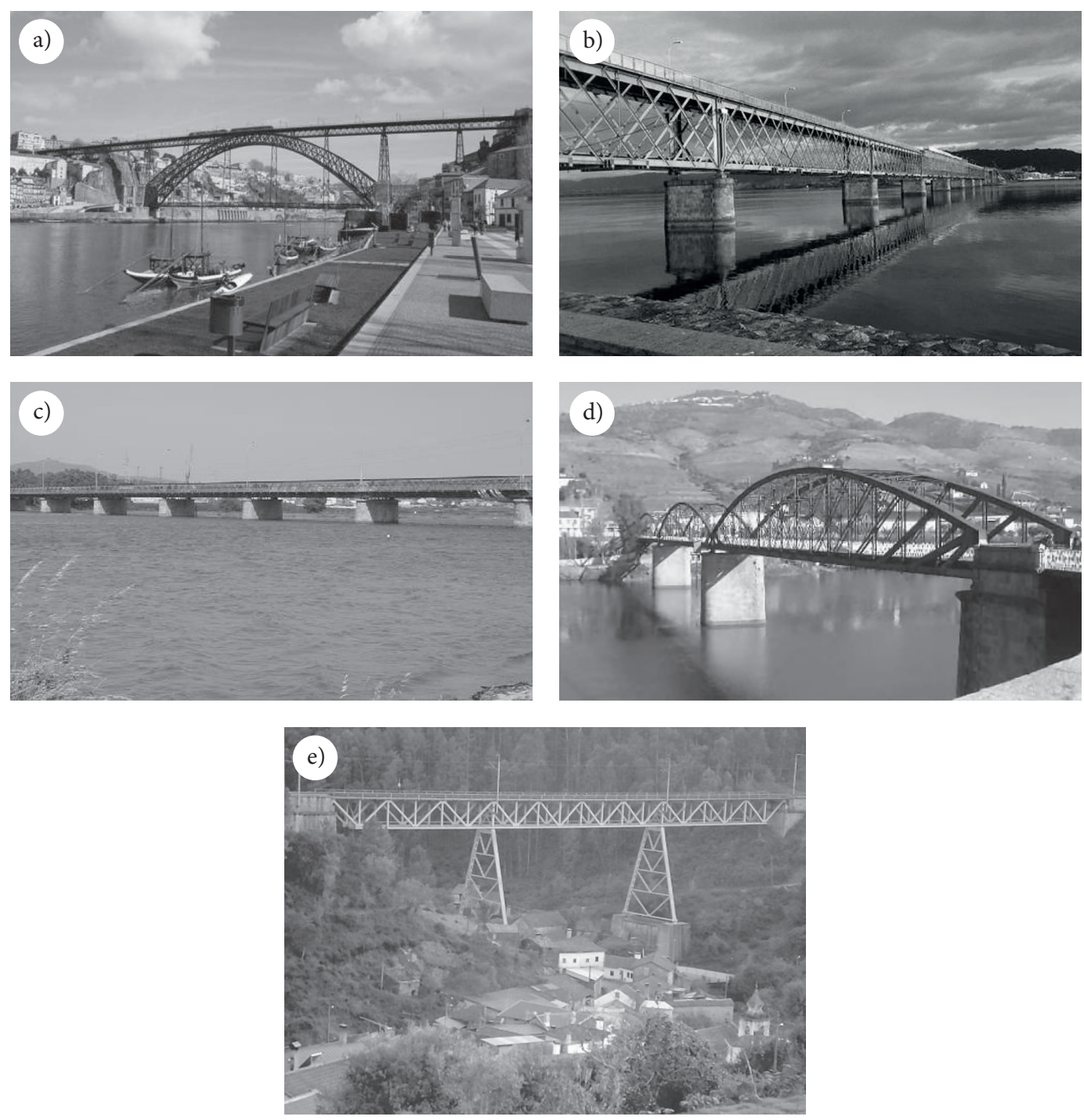

Fig. 1. (a) Luiz I bridge (adapted from Fernandes et al. 2004); (b) Eiffel bridge (adapted from Jesus et al. 2011); (c) Fão bridge (adapted from De Jesus et al. 2014a); (d) Pinhão bridge (adapted from Figueiredo et al. 2004);

(e) Trezói bridge (adapted from Correia et al. 2008a) 
$6 \mathrm{~m}$ (Correia et al. 2008b). The highway Fão bridge (Fig. 1c) was inaugurated in 1892 and connects Fão to Esposende (Silva 2009b). The length of the bridge is $267 \mathrm{~m}$ and width is $9.44 \mathrm{~m}$ (Correia et al. 2008b). The longest span has $38.5 \mathrm{~m}$ (Correia et al. 2008b). The Pinhão railway bridge (Fig. 1d) was designed by Gustave Eiffel and built between 1903 and 1906. The bridge links Pinhão to São João da Pesqueira and Peso da Régua. The bridge is composed by three spans with $68.8 \mathrm{~m}$ each and one span with $10 \mathrm{~m}$ (Correia et al. 2008b). The width of the deck is $6 \mathrm{~m}$, with one traffic lane with $4.60 \mathrm{~m}$ and two sidewalks with $0.675 \mathrm{~m}$ each. The Trezói railway bridge (Fig. 1e) was inaugurated in 1956 and is part of the Beira Alta railway line (Correia et al. 2008b). The total length of the bridge is $126 \mathrm{~m}$, and is composed by three continuous spans of 39,48 and $39 \mathrm{~m}$ and the width of the deck is $4.40 \mathrm{~m}$ (Correia et al. 2008b).

\section{Monotonic tensile strength}

The tensile strength tests were performed in the original materials of the bridges that were replaced for new ones. A diagonal of $1600 \mathrm{~mm}$ was removed from the Luiz I bridge, a diagonal with a length of $1500 \mathrm{~mm}$ and a bracing with $1400 \mathrm{~mm}$ were removed from the Pinhão bridge and a bracing with $3000 \mathrm{~mm}$ was extracted from the Trezói bridge (Raposo et al. 2017). The Eiffel bridge was under a process of rehabilitation where the highway viaduct was removed and replaced by a new one, and the material for testing was extracted from the girder of this viaduct (Raposo et al. 2017). The Fão bridge was rehabilitated in 2007 and seven diagonals were removed and replaced by new ones, being the material used for testing from those diagonals.

\subsection{Principle of the test}

The monotonic tensile tests followed the principles of the Portuguese Standard NP EN 10002-1. The specimens geometry was round (Fig. 2), machined from the original members extracted from the five bridges under study. The dimensions of the specimens are presented in Table 1. The number of specimens prepared was:

- Luiz I bridge: 5 specimens from the diagonal member;

- Eiffel bridge: 4 specimens in the longitudinal and 4 in the transverse directions of the girder;

- Fão bridge: 22 specimens from the diagonal;

- Pinhão bridge: 14 specimens, 7 from the diagonal and 7 from the bracing;
- Trezói bridge: 3 specimens from the bracing member.

The test consists in the application of a monotonic increasing tensile load in the specimens. The materials extracted from the bridges presented distinct sizes so different diameters were selected for the specimens (Table 1). The strength and elastic properties (Young's modulus, $E$, and Poisson's ratio, $v$ ) were estimated.

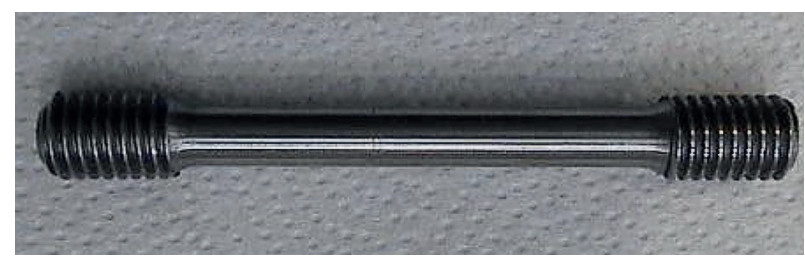

Fig. 2. Typical specimen used in the monotonic tensile tests

Table 1. Cross-sections of the specimens used in the monotonic tensile tests of the old steels

\begin{tabular}{|c|c|c|c|}
\hline $\begin{array}{c}\text { Bridge } \\
\text { material }\end{array}$ & Origin & $\begin{array}{c}\text { Diameter, } \\
\mathrm{mm}\end{array}$ & $\begin{array}{c}\text { Cross-section, } \\
\mathrm{mm}^{2}\end{array}$ \\
\hline \multirow{2}{*}{ Luiz I } & Diagonal & 6 & 28.27 \\
\cline { 2 - 4 } & Diagonal & 8 & 50.27 \\
\hline \multirow{3}{*}{ Eiffel } & Viaduct & 4 & 12.57 \\
\cline { 2 - 4 } & Viaduct & 5 & 19.63 \\
\cline { 2 - 4 } & Viaduct & 6 & 28.27 \\
\hline \multirow{2}{*}{ Fão } & Diagonal & 6 & 28.27 \\
\hline \multirow{2}{*}{ Pinhão } & Diagonal & 5 & 19.63 \\
\cline { 2 - 4 } & Bracing & 8 & 50.27 \\
\hline \multirow{2}{*}{ Trezói } & Bracing & 8 & 50.27 \\
\hline
\end{tabular}

\subsection{Results}

The modulus of elasticity, $E$, and the Poisson's ratio, $v$, of the materials extracted from Luiz I and Fão bridges were acquired directly from the strain gauge measurements. The elastic properties of the old steels from the Eiffel and Trezói bridges were obtained indirectly from cyclic elastoplastic analysis. In Table 2 are presented the estimates of the monotonic tensile strength, namely the ultimate strength, $f_{u}$, the yield strength, $f_{y}$, the elongation at the fracture, $A$, the reduction in cross section at fracture, $Z$, and elastic properties, such as Young's modulus, $E$, and Poisson's ratio, $v$, of all the materials from old Portuguese metallic bridges. As it can be seen in Table 2 the materials extracted from Luiz I, Eiffel and Fão bridges have properties similar with puddled steel and the materials from Pinhão and Trezói bridges present a monotonic tensile strength behaviour alike mild steel. 
Table 2. Monotonic tensile and elastic properties of the steels

\begin{tabular}{|c|c|c|c|c|c|c|}
\hline Bridge Material & $f_{u}, \mathrm{MPa}$ & $f_{y}, \mathrm{MPa}$ & $A, \%$ & $Z, \%$ & $E, \mathrm{GPa}$ & $v$ \\
\hline Luiz I & 396.60 & 302.60 & 21.20 & 27.18 & 192.70 & 0.26 \\
\hline Eiffel & 341.75 & 292.38 & 8.14 & 11.60 & 193.10 & 0.3 \\
\hline Fão & 359.33 & 219.90 & 23.13 & 13.06 & 198.70 & 0.26 \\
\hline Pinhão & 361.06 & 305.89 & 33.19 & 70.97 & 210.68 & - \\
\hline Trezói & 473.33 & 398.33 & 23.00 & 66.33 & 198.49 & 0.32 \\
\hline
\end{tabular}

\section{Chemical composition and microstructures}

The materials extracted from the five bridges under study (Luiz I, Eiffel, Fão, Pinhão and Trezói), with exception of the materials from Eiffel bridge, exhibits a homogeneous ferrite microstructure of regular grains. The material from Eiffel bridge presents a ferrite microstructure with different grain sizes and high level of inclusions. The materials revealed a relative good homogeneity in terms of chemical composition.

\subsection{Chemical composition}

The chemical composition was studied using the spark emission spectrometry technique. The Table 3 summarizes the chemical composition of the samples of the materials from the old metallic bridges. The chemical analysis, in general, showed a relative good homogeneity of the materials. The contents of phosphorus $(P)$ and sulphur $(S)$ are low and are within the acceptable values for modern steels. The materials extracted from the Luiz I, Eiffel and Fão bridges are more similar, chemically, with puddle streel while the materials from Pinhão and Trezói bridges are similar to current mild steels.

\subsection{Microstructures}

Samples from materials from old Portuguese bridges were analysed in a microscope and their microstructure is presented in Figure 4 to Figure 7. In general, the materials are composed of a ferrite microstructure. The material from Pinhão and Trezói bridges presented perlite, with a more homogeneous microstructure of regular grains than the other materials.

In Figure 3 is presented the microstructure of the materials extracted from Luiz I bridge. The material is composed by ferrite, as expected from the observation of the chemical composition results (Table 3 ), due to the low carbon $(\mathrm{C})$ and manganese $(\mathrm{Mn})$ contents, with low volume fraction of perlite.

The microstructure of the material from Darque viaduct from Eiffel bridge is presented in Figure 4. In this figure is observed a ferrite microstructure with a high level of inclusions and different grain sizes. The material from the web of the longitudinal member (girder) exhibits a higher level of inclusions and greater grain sizes than the material from the bracing member.

Figure 5 shows the microstructure of the original material from Fão bridge. This figure shows a ferrite structure and inhomogeneous grain size. Also is observed a significant amount of inclusions/heterogeneities, typical of puddle irons, the precursor of modern construction steels.

The microstructures of the diagonal and bracing members of the Pinhão bridge are presented in Fig. 6a and $b$, respectively. This material has a ferrite microstructure with low content of perlite and some aligned inclusions.

Table 3. Chemical composition of the materials (wt.\%)

\begin{tabular}{|c|c|c|c|c|c|c|c|}
\hline Bridge & Material & C, \% & Si, \% & Mn, \% & P, \% & S, \% \\
\hline \multirow{2}{*}{ Luiz I } & Diagonal & 0.72 & 0.34 & 2.09 & $>0.15$ & $>0.15$ \\
\hline \multirow{2}{*}{ Eiffel } & Darque viaduct & 0.23 & 0.39 & 1.78 & $>0.15$ & $>0.15$ \\
\cline { 2 - 8 } & Bridge* & 0.81 & 0.24 & 2.71 & $>0.15$ & $>0.15$ \\
\hline \multirow{2}{*}{ Pão } & Diagonal & 0.09 & 0.06 & 0.13 & 0.14 & 0.007 \\
\hline \multirow{2}{*}{ Trezói } & Diagonal & 0.06 & $<0.01$ & 0.04 & 0.04 & 0.03 \\
\cline { 2 - 8 } & Bracing & 0.05 & $<0.01$ & 0.34 & 0.04 & 0.04 \\
\hline
\end{tabular}

Note: ${ }^{\star}$ Determined with a portable emission spectrometry. 
a) $200 \mu \mathrm{m}$

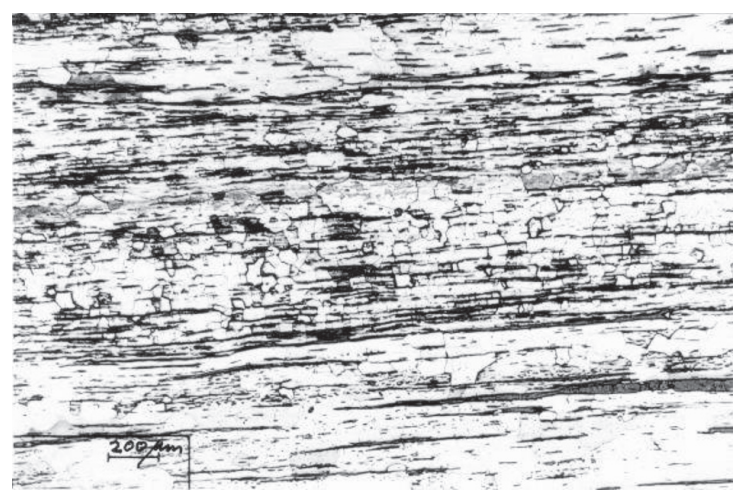

b) $20 \mu \mathrm{m}$

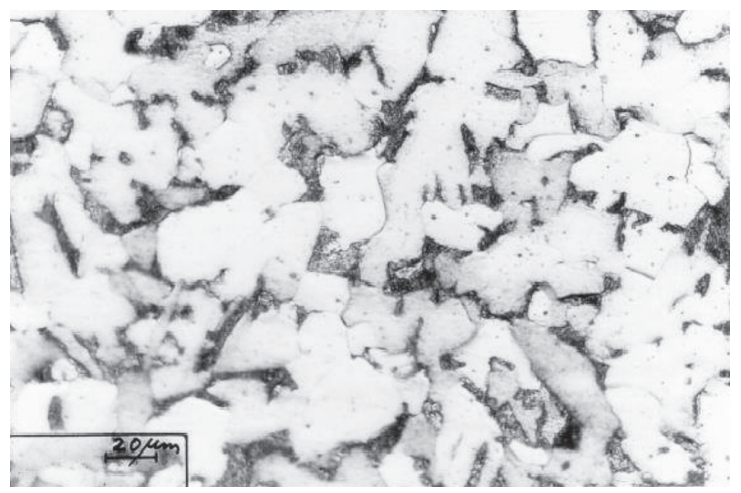

Fig. 3. Microstructures of the material from the Luiz I bridge

a) Web of the longitudinal member of girder

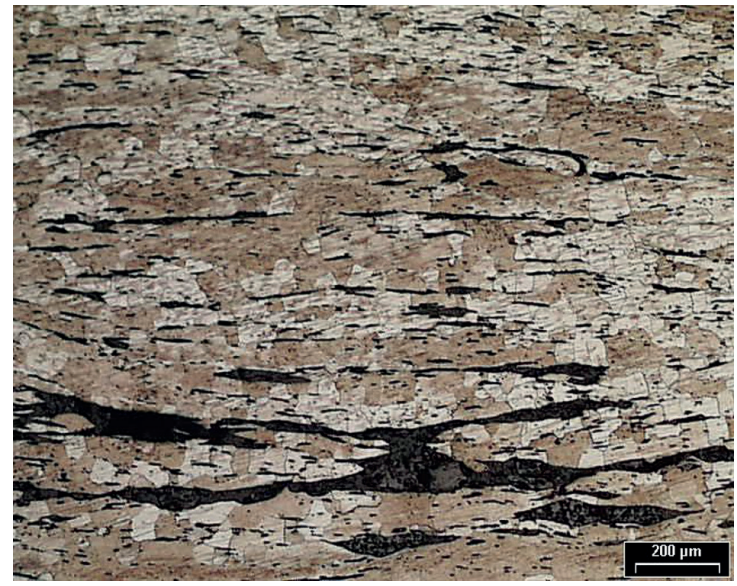

b) Bracing member

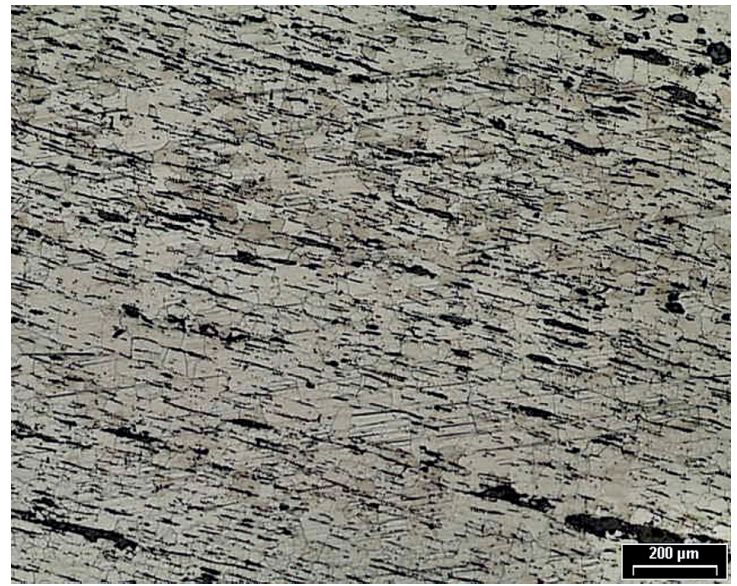

Fig. 4. Microstructures of the material from the Eiffel bridge

a) $200 \mu \mathrm{m}$

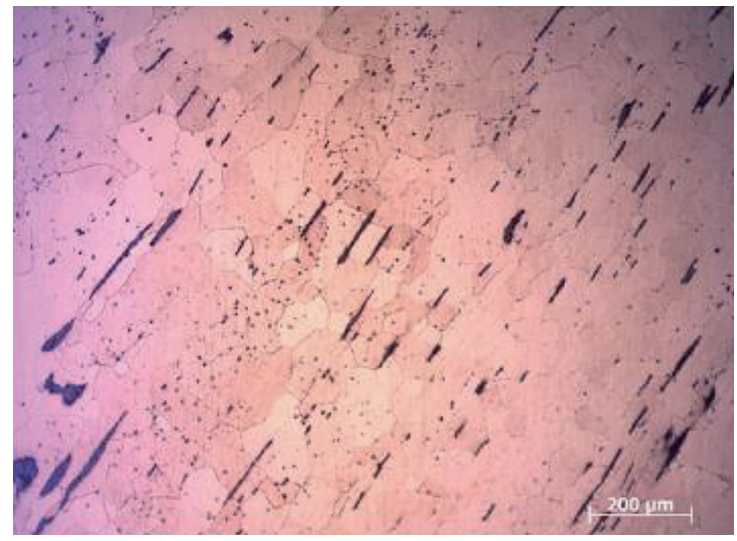

b) $50 \mu \mathrm{m}$

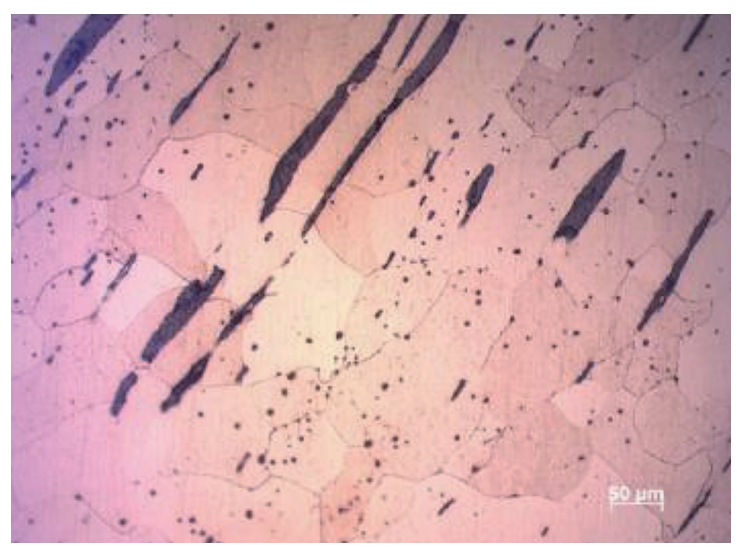

Fig. 5. Microstructures of the material from the Fão bridge

Finally, the Figure 7 presents the microstructure for the material from the Trezói bridge. In this material is observed, essentially, a ferrite microstructure, which is expectable due to the low carbon content observed in the chemical analysis (Table 3 ). The material micro- structure of the bracing member (parallel to the rolling direction), presented in Figure 7 a) is composed of grains of ferrite, some lined up inclusions and small amounts of perlite. 
a) Diagonal member

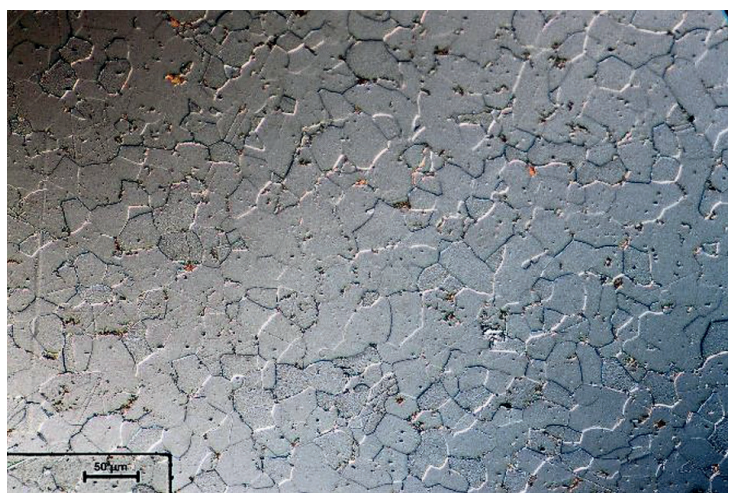

b) Bracing member

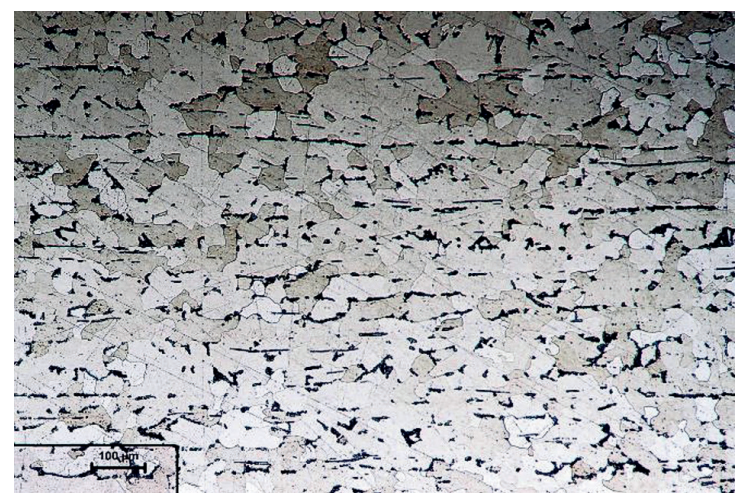

Fig. 6. Microstructures of the material from the Pinhão bridge

a) Parallel to the rolling direction (bracing member)

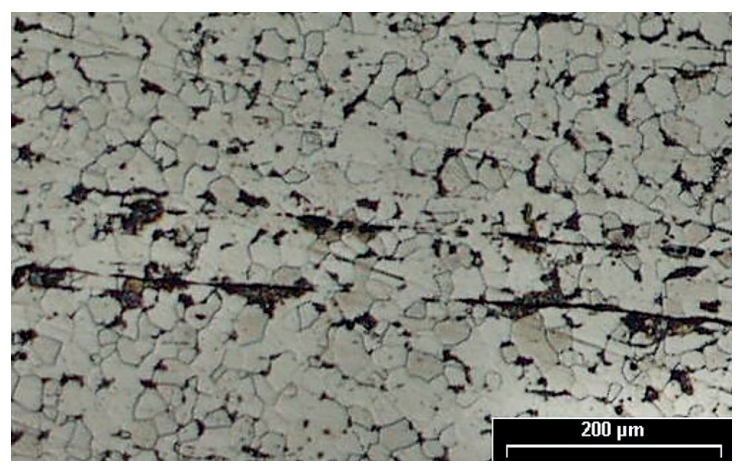

b) transverse to the rolling direction (bracing member)

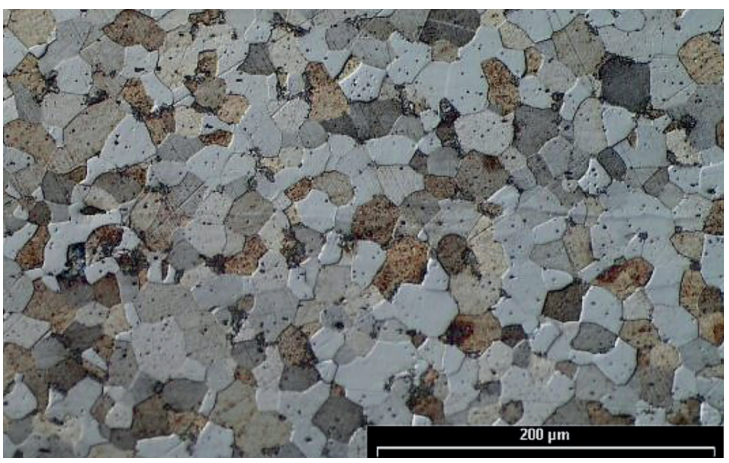

Fig. 7. Microstructures of the material from the Trezói bridge

\section{Hardness analysis}

The hardness of the materials of the bridges was measured with Vickers hardness test, accordingly to the procedures of the NP EN 10045 standard. The test was performed for: 3 samples of the material from the diagonal of the Luiz I bridge; 2 samples of the material from the diagonals from Fão bridge; 3 samples of the material from the diagonal and 3 samples of the bracing of the Pinhão bridge; 3 samples of the material from the bracing of the Trezói bridge.

The average hardness of the material from: Luiz I bridge is $158 \mathrm{HV}$ 50; Fão bridge is $63.1 \mathrm{HV}$ from 22 measurements, with a standard deviation of $4.7 \mathrm{HV}$ (Silva 2009a); Pinhão bridge from the diagonal and bracing, is $108 \mathrm{HV} 40$ and $116 \mathrm{HV} 40$, respectively; Trezói bridge is $136 \mathrm{HV}$ 40. The data of Eiffel bridge is not available (De Jesus et al. 2011; Figueiredo et al. 2004, 2006; Jorge et al. 2006; Correia et al. 2008a).

\section{Notch toughness}

The notch toughness of the materials from the five bridges was measured using both Charpy V-notch impact and COD tests. The Charpy V-notch impact tests were carried out according to the procedures of NP 10045-1 standard for several temperatures. The COD tests were conducted following the procedures of the BS 5762 standard. The thicknesses of the specimens were limited by the thickness of the members extracted from the bridges. In Table 4 and Table 5 is presented a summary of the Charpy V-notch and COD test results, respectively. The minimum allowable Charpy V-notch strength, according to Eurocode, for a material classified according to the EN 10025 Class B (same type of the material studied), should be $27 \mathrm{~J}$ at a specified temperature. According to this principle, only the material from the Pinhão bridge exhibits acceptable toughness properties. The materials from the other bridges exhibit relatively low toughness properties. 
Table 4. Charpy-V tests

\begin{tabular}{|c|c|c|c|c|c|c|}
\hline Bridge & Origin & Direction & Thickness, mm & Specimens, No & Energy, J & Temperature, ${ }^{\circ} \mathrm{C}$ \\
\hline \multirow{2}{*}{ Luiz I } & \multirow{2}{*}{ Diagonal } & \multirow{2}{*}{ Longitudinal } & \multirow{2}{*}{6} & 5 & 13 & 0 \\
\hline & & & & 11 & 14 & 22 \\
\hline Eiffel & Viaduct & Longitudinal & 5 & - & 7 & 0 \\
\hline Fão & Diagonal & Not available & Not available & Not available & Not available & Not available \\
\hline \multirow{4}{*}{ Pinhão } & \multirow{2}{*}{ Bracing } & Longitudinal & \multirow{2}{*}{7.5} & 4 & 89 & 19 \\
\hline & & Transverse & & 4 & 26 & 19 \\
\hline & \multirow{2}{*}{ Diagonal } & Longitudinal & \multirow{2}{*}{7.5} & 4 & 107 & 19 \\
\hline & & Transverse & & 4 & 20 & 19 \\
\hline \multirow{4}{*}{ Trezói } & \multirow{4}{*}{ Bracing } & \multirow{2}{*}{ Longitudinal } & \multirow{4}{*}{10} & 5 & 24 & 26.5 \\
\hline & & & & 3 & 6 & -10 \\
\hline & & \multirow{2}{*}{ Transverse } & & 4 & 16 & 26.5 \\
\hline & & & & 4 & 4 & -10 \\
\hline
\end{tabular}

Table 5. COD tests

\begin{tabular}{|c|c|c|c|c|c|c|c|}
\hline Bridge & Origin & Direction & $\begin{array}{l}\text { Thickness, } \\
\text { mm }\end{array}$ & $\begin{array}{c}\text { Specimens, } \\
\text { No }\end{array}$ & $\begin{array}{c}\text { COD "pop-in", } \\
\text { mm }\end{array}$ & $\begin{array}{c}\mathrm{COD} F_{\max } \\
\mathrm{mm}\end{array}$ & $\begin{array}{c}\text { Temperature, } \\
{ }^{\circ} \mathrm{C}\end{array}$ \\
\hline \multirow{3}{*}{ Luiz I } & \multirow{3}{*}{ Diagonal } & Longitudinal & \multirow{3}{*}{6} & 1 & 0.343 & 1.360 & 20 \\
\hline & & Longitudinal & & 1 & 0.236 & 0.940 & -1 \\
\hline & & Longitudinal & & 2 & 0.173 & 0.950 & 18 \\
\hline Eiffel & Viaduct & Not available & Not available & Not available & Not available & Not available & Not available \\
\hline Fão & Diagonal & Not available & Not available & Not available & Not available & Not available & Not available \\
\hline \multirow{3}{*}{ Pinhão } & Bracing & Longitudinal & 7 & 3 & 0.017 & 0.765 & 24 \\
\hline & \multirow{2}{*}{ Diagonal } & Longitudinal & \multirow{2}{*}{9} & 2 & 0.030 & 0.972 & 22 \\
\hline & & Longitudinal & & 1 & 0.022 & 0.905 & 19 \\
\hline \multirow{2}{*}{ Trezói } & \multirow{2}{*}{ Bracing } & \multirow{2}{*}{ Longitudinal } & \multirow{2}{*}{9} & 7 & 0.028 & 1.188 & 26.5 \\
\hline & & & & 4 & 0.030 & 0.720 & -10 \\
\hline
\end{tabular}

\section{Fatigue crack propagation rates}

\subsection{Specimens geometry and tests conditions}

The fatigue crack propagation rates of the material from old metallic bridges is also concern of this study. The crack growth tests were conducted according to ASTM E647 (ASTM International 2015). The compact tension (CT) geometry was used for all cases with the exception of the Luiz I bridge, for which the middle tension geometry (MT) was adopted. Were tested 4 specimens from the Luiz I bridge, 5 specimens ( 1 according the longitudinal direction and 4 according the transverse direction) from the Eiffel bridge, 12 specimens of the Fão bridge, 13 specimens ( 6 from the diagonal and 7 from the bracing) from the Pinhão bridge, and finally 8 specimens from the Trezói bridge. Due to limitations in material availability, distinct dimensions for the specimens were adopted as is presented in Table 6.
Table 6. Properties of the specimens of the materials of each bridge

\begin{tabular}{|c|c|c|c|c|}
\hline Bridge & Geometry & $\begin{array}{c}\text { Thickness, } \\
\mathrm{mm}\end{array}$ & $\begin{array}{c}\text { Width, } \\
\mathrm{mm}\end{array}$ & $\begin{array}{c}\text { Stress } \\
\text { ratio, } \mathrm{R}\end{array}$ \\
\hline Luiz I & MT & 10 & 40 & 0.1 \\
\hline Eiffel & $\mathrm{CT}$ & 4.35 & 40 & 0.1 \\
\hline & & & & 0.5 \\
\hline Fão & $\mathrm{CT}$ & 8 & 60 & 0.0 \\
& & & & 0.25 \\
& & & & 0.75 \\
\hline \multirow{2}{*}{ Pinhão } & $\mathrm{CT}$ & 4.35 & 40 & 0.0 \\
& & & & 0.1 \\
\hline \multirow{2}{*}{ Trezói } & CT & \multirow{2}{*}{8} & 50 & 0.25 \\
& & & & 0.5 \\
\hline
\end{tabular}


The fatigue tests were performed in air, at room temperature, under a sinusoidal waveform with a frequency of $20 \mathrm{~Hz}$ for all the materials except the material from Luiz I bridge, which was tested under a frequency of $10 \mathrm{~Hz}$.

\subsection{Results and discussion}

The Figures 8, 9, 10, 11 and 12 present the experimental results obtained for the specimens of the materials from Luiz I, Eiffel, Fão, Pinhão and Trezói bridges, respectively. The power law was used to make the correlation of the results, as proposed by Paris \& Erdogan (1963), and presented in equation (1) (De Jesus et al. 2010; Hafezi et al. 2012; Correia 2012; Correia et al. 2017).

$$
\frac{d a}{d N}=C_{p} \cdot \Delta K^{m_{p}}
$$

where $d a / d N$ is the crack propagation rate; $\Delta K$ is the stress intensity factor range and $C, m$ are material constants. The results from the specimens from Luiz I, Eiffel and Fão bridges presented the highest scatter, which is consistent with the age of those bridges, since they are the oldest ones, and their materials show important heterogeneities. The Pinhão bridge results revealed a relative low scatter, which is also consistent since this material is about 25 years younger than the materials from the previous ones, revealing good homogeneity, similar to the modern steels. Trezói bridge, which is the most recent, presents very low scatter.

The Eiffel bridge is the most affected by the stress ratio influence. The crack propagation rates of the material of this bridge were measured in the girder longitudinal (L) direction and only one test was performed in the transverse direction $(\mathrm{T})$. The transverse direction $(\mathrm{T})$ test suggests a lower crack propagation rate in this direction.

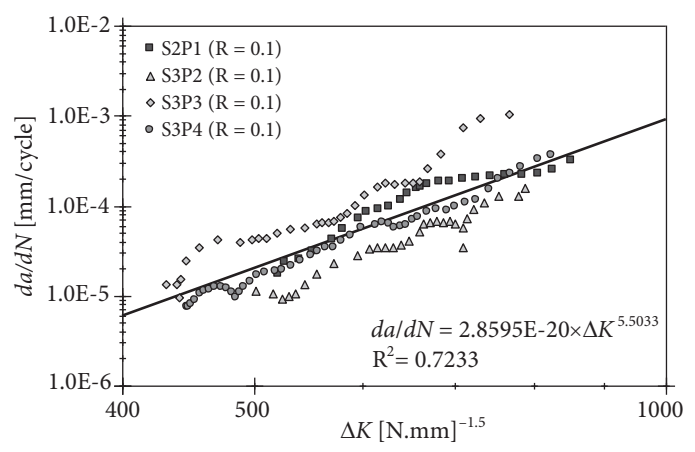

Fig. 8. Fatigue crack growth data of the material from the Luiz I bridge: $\mathrm{R}=0.1$
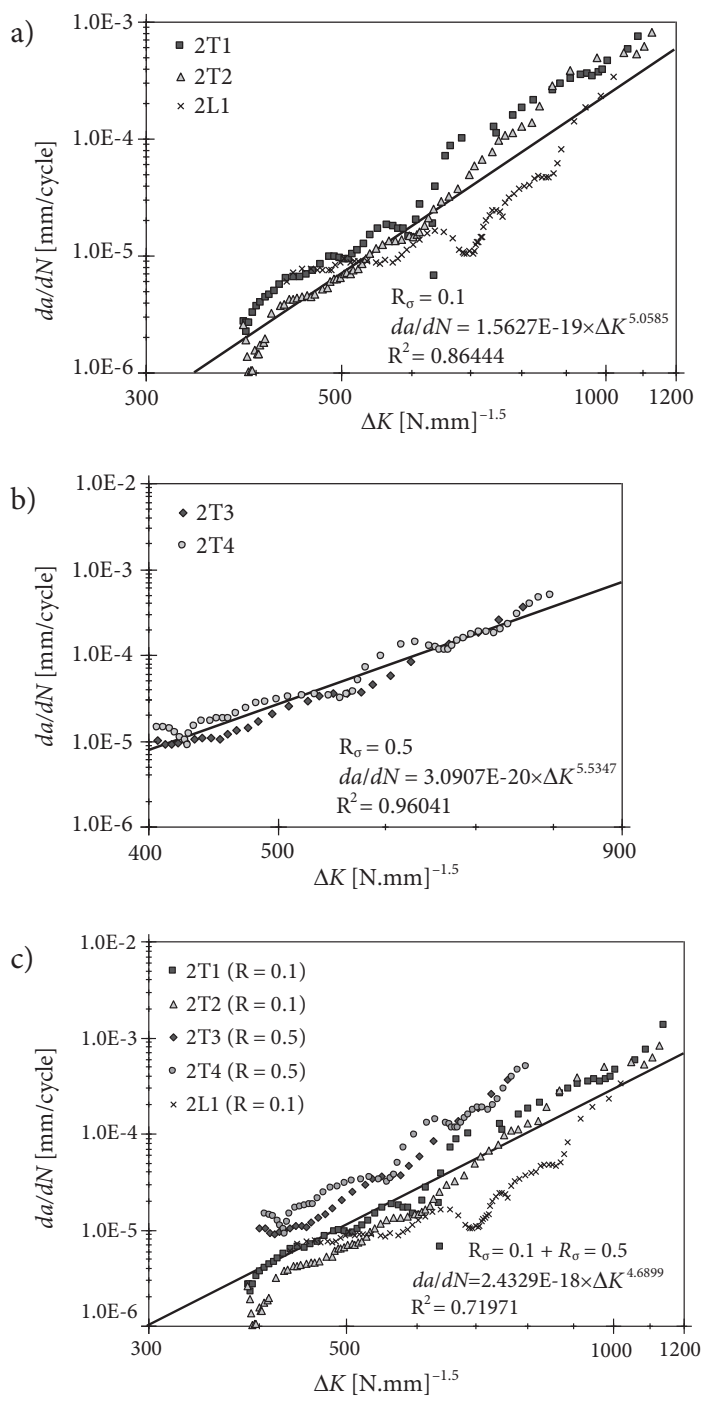

Fig. 9. Fatigue crack growth data of the material from the Eiffel bridge: a) $\mathrm{R}=0.1$; b) $\mathrm{R}=0.5$; c) $\mathrm{R}=0.1+\mathrm{R}=0.5$

The Fão bridge material is influenced by the stress ratio, having the lowest scatter for $\mathrm{R}=0.25$ and $\mathrm{R}=$ 0.75 .

The material from the bracing (B) and diagonal (D) of the Pinhão bridge exhibits slightly different crack growth rates for $\mathrm{R}=0.0$, which not occur for the other stress ratios.

The crack propagation rate of the material from the Trezói bridge slightly increases as the stress ratio increases, so this material is also sensitive to the stress ratio.

In Figure 13 are presented the results obtained for the materials of all the bridges. It was derived a unique relation for all data together. A linear regression was applied, resulting in a determination coefficient, $\mathrm{R}^{2}=$ 0.74 , which is a high value, considering the different origins of the materials studied. In Figure 13 can be 

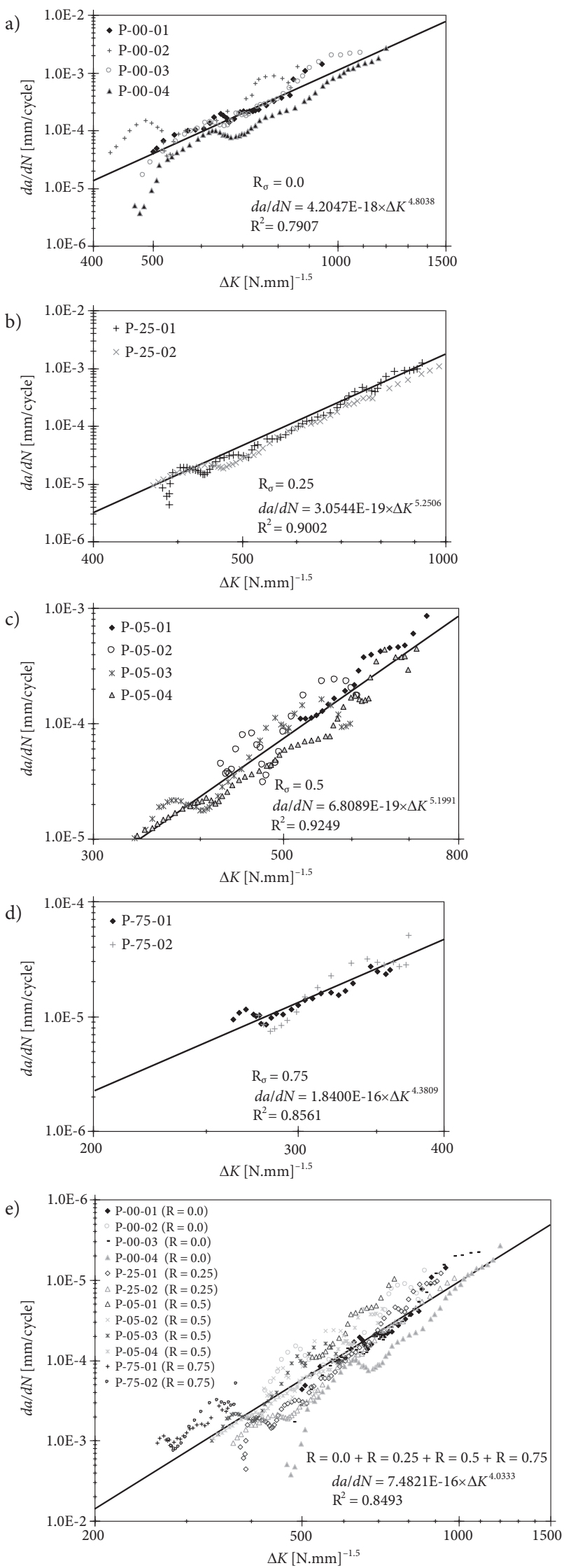

Fig. 10. Fatigue crack growth data of the material from the Fão bridge: a) $\mathrm{R}=0.1$; b) $\mathrm{R}=0.25$; c) $\mathrm{R}=0.5$; d) $\mathrm{R}=0.75$; e) $\mathrm{R}=0.0+\mathrm{R}=0.25+\mathrm{R}=0.5+\mathrm{R}=0.75$
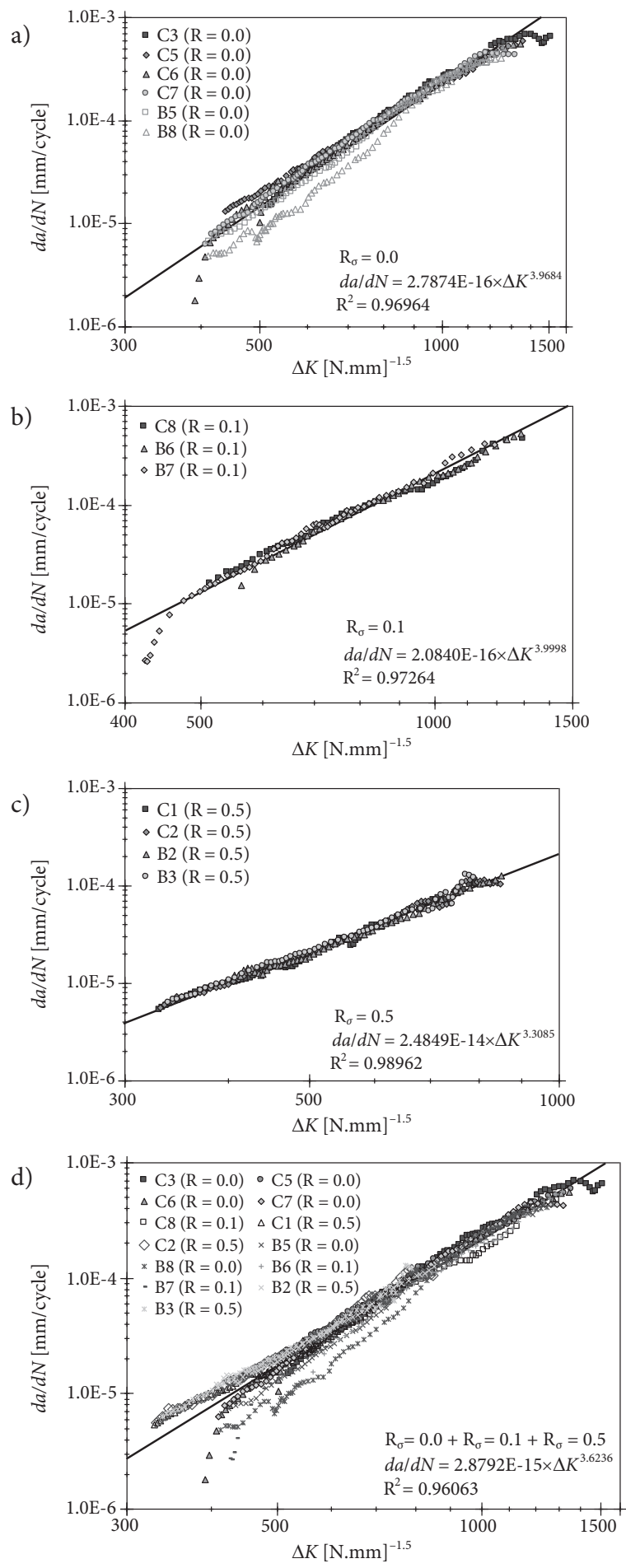

Fig. 11. Fatigue crack growth data of the material from Pinhão bridge: a) $\mathrm{R}=0.0$; b) $\mathrm{R}=0.1$; c) $\mathrm{R}=0.5$; d) $\mathrm{R}=0.0+\mathrm{R}=0.1+\mathrm{R}=0.5$ 
observed the divergence of the values of the material from Luiz I and Fão bridges from the mean values, resulting in higher crack propagation values. It is also possible to detect that one specimen of the Eiffel bridge exhibits lower crack propagation rates for intermediate stress intensity factor ranges. The Paris's law constant,
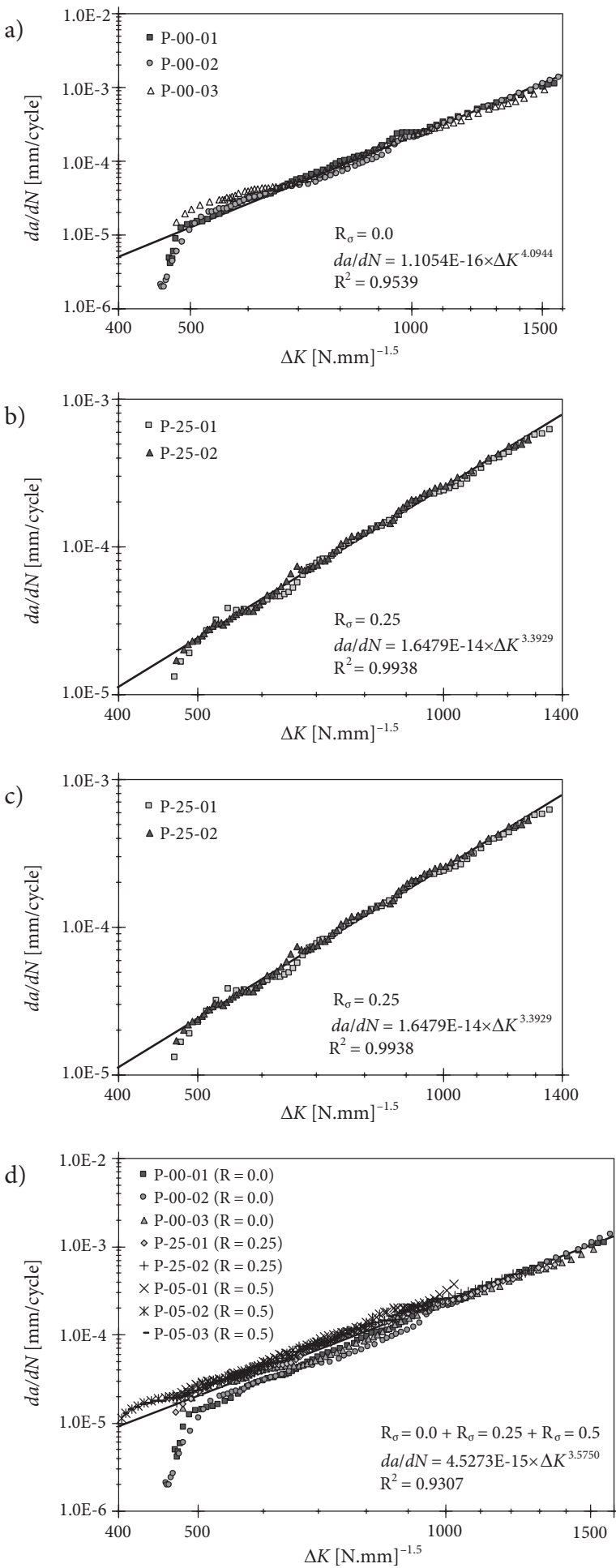

Fig. 12. Fatigue crack growth data of the material from the Trezói bridge: a) $\mathrm{R}=0.0$; b) $\mathrm{R}=0.25$; c) $\mathrm{R}=0.5$; d) $R=0.0+R=0.25+R=0.5$ $m$, obtained for the results of all the materials is higher than 3.0, being this value usually adopted in current design codes of practice indirectly as the slope of S-N curve of structural details (Acier 1996). In the existing literature for modern steels (Acier 1996) is recommended a value of $C$ : $1.2 \times 10^{-13} \leq C \leq 5 \times 10^{-13}$, being the obtained value significantly lower. In Figure 13 was also defined an upper boundary that can be used for design purposes, parallel to the linear regression of the results. Some of the results of the Luiz I and Fão bridges are above the upper boundary, however these values correspond to the phase III of crack propagation. Considering the slope, $m=3$ was designed another upper boundary, in which the value of $C$ is also different from the referred in the literature, being bigger (Acier 1996). A design crack propagation curve with a slope, $m=3$ and a $C=2.0 \times 10^{-12}$ will lead to safer results for all the materials studied. For this latter case, the $C$ constant happens to be higher than the values referred in literature for modern steels (Acier 1996).

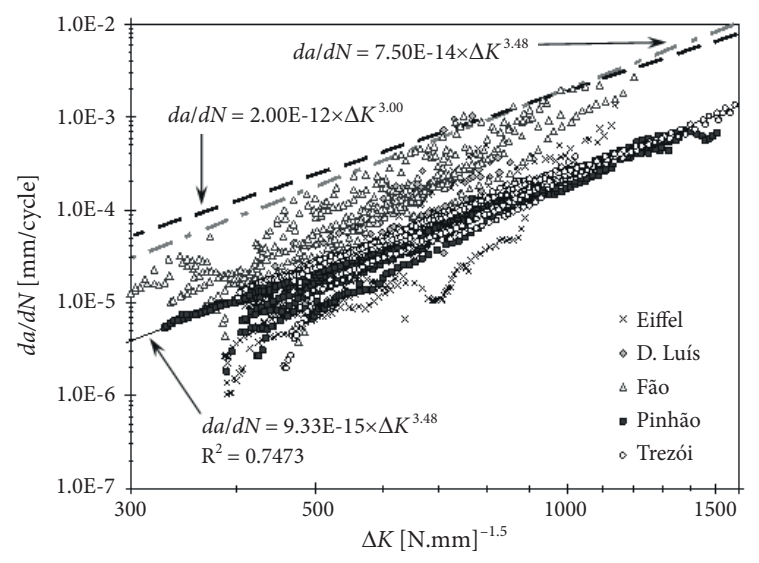

Fig. 13. Crack growth data for all materials

\section{Concluding remarks}

The study of the structural degradation of the old steels is of great importance in order to perform intervention and repairing operations in old steel structures.

In this study was observed that, in general, a significant correlation between the mechanical performance of the materials and their age. The older the materials, the lower were the mechanical properties, which is correlated with the production techniques since they evolved with time and the newer the materials, the better is their quality.

The material from Trezói bridge presents higher strength properties, expectable since is closer to modern steels. In terms of monotonic tensile tests, the ma- 
terials from Luiz I, Eiffel and Fão bridges are similar to puddle steel and the materials from Pinhão and Trezói bridges are similar to mild steel. In the studied materials was spotted, when comparing the yield and ultimate strengths a relative small strain hardening, when compared with actual steels. This behaviour is compatible with the microstructure of ferrite with low volumetric fraction of perlite.

In general, the studied materials present high ductility, with the exception of Eiffel bridge material, since it presents a relative small ductility, which could be justified by the high level of inclusions observed in the microstructure.

The materials extracted from the Luiz I, Eiffel and Fão bridges, chemically, are similar to puddle streel while the materials from Pinhão and Trezói bridges are analogous to current mild steels. In general, the materials are composed of a ferrite microstructure. The material from Pinhão and Trezói bridges presented perlite, with a more homogeneous microstructure of regular grains than the other materials.

In terms of toughness only the material from the Pinhão bridge exhibits acceptable toughness properties, considering current design requirements. The materials from the other bridges exhibit relatively low toughness properties.

The fatigue crack propagation results showed that the Paris law gives a good description of the fatigue crack growth data, for each stress ratio. The exponent of the Paris law resulted always greater than the value suggested by codes of practice $(m=3)$ and $C$ coefficient was in order of magnitude lower than that recommended in literature for modern construction steels. A design fatigue crack propagation curve was proposed taking into account 42 fatigue crack propagation tests for the material from five distinct Portuguese riveted steel bridges.

\section{Acknowledgements}

The authors acknowledge the Portuguese Science Foundation (FCT) for the financial support through the doctoral and post-doctoral grants, SFRH/BD/135257/2017 and SFRH/BPD/107825/2015, respectively. Authors gratefully acknowledge the funding of SciTech - Science and Technology for Competitive and Sustainable Industries (NORTE-01-0145-FEDER-000022), R\&D project cofinanced by Programa Operacional Regional do Norte ("NORTE2020"), through Fundo Europeu de Desenvolvimento Regional (FEDER).

\section{References}

Acier, A.-A. P. L. P. D. L. E. D. L. C. 1996. Construction métallique et mixte acier-béton: Calcul et dimensionnement selon les Eurocodes 3 et 4, Paris (in French).

Correia, J. A. F. O.; De Jesus, A. M. P.; Figueiredo, M. A. V.; Ribeiro, A. S.; Fernandes, A. A. 2008a. Fatigue assessment of riveted railway bridge connections. Part I: Experimental investigations, in Steel brigdes. Advances solutions and technologies, ECCS, 329-338.

Correia, J. A. F. O.; Jesus, A. M. P.; Figueiredo, M. A. V.; Ribeiro, A. S.; Fernandes, A. A. 2008b. Variability analysis of fatigue crack growth rates of materials from ancient Portuguese steel bridges, in C. Press (Ed.). Bridge maintenance, safety management, health monitoring and informatics (IABMAS '08), 13-17 July 2008, Seoul, Korea. 290.

Correia, J. A. F. O.; De Jesus, A. M. P.; Fernández-Canteli, A. 2012. A procedure to derive probabilistic fatigue crack propagation data, International Journal Structural Integrity 3: 158-183. https://doi.org/10.1108/17579861211235183

Correia, J. A. F. O.; De Jesus, A. M. P.; Silva, A.L.L.; Pedrosa, B.; Rebelo, C.; Calçada, R. 2017. FE simulation of S-N curves for a riveted connection using two-stage fatigue models, $A d$ vances in Computational Design, an International Journal 2: 333-348.

De Jesus, A. M. P.; Pinto, H.; Fernández-Canteli, A.; Castillo, E.; Correia, J. A. F. O. 2010. Fatigue assessment of a riveted shear splice based on a steel probabilistic model, International Journal of Fatigue 32: 453-462. https://doi.org/10.1016/j.ijfatigue.2009.09.004

De Jesus, A. M. P. ; Silva, A. L. L. D.; Figueiredo, M. V.; Correia, J. A. F. O.; Ribeiro, A. S.; Fernandes, A. A. 2011. Strain-life and crack propagation fatigue data from several Portuguese old metallic riveted bridges, Engineering Failure Analysis 18: 148-163. https://doi.org/10.1016/j.engfailanal.2010.08.016

De Jesus, A. M. P.; Silva, A. L. L. D.; Correia, J. A. F. O. 2014a. Fatigue of riveted and bolted joints made of puddle iron - an experimental approach, Journal of Constructional Steel Research 104: 81-90. https://doi.org/10.1016/j.jcsr.2014.10.012

De Jesus, A. M. P.; Silva, A. L. L. D.; Correia, J. A. F. O. 2014 b. Fatigue of riveted and bolted joints made of puddle iron - a numerical approach, Journal of Constructional Steel Research 102: 164-177. https://doi.org/10.1016/j.jcsr.2014.06.012

Fernandes, A. A.; Castro, P. T.; Figueiredo, M.; Oliveira, F. 2004. Structural integrity evaluation of highway riveted bridges, in W. E. E. Al. (Ed.). Bridge maintenance, safety and management (IABMAS’04), 18-22 October 2004, Kyoto.

Figueiredo, M.; Jesus, A.; Pereira, H.; Ribeiro, A.; Natal, R.; Moreira, P.; Castro, P. T.; Fernandes, A. A. 2004. Avaliação da integridade estrutural da Ponte do Pinhão, IDMEC/FEUP (in Portuguese).

Figueiredo, M.; Jesus, A. M. P.; Ribeiro, A. S.; Castro, P. M. S. T.; Fernandes, A. A. 2006. Fatigue behaviour of riveted steel lap joints, in P. J. S. C. E., AI (Ed.). Bridge maintenance, safety and management (IABMAS'06), 2006 Porto.

Hafezi, M. H.; Abdullah, N. N.; Correia, J. F.O.; De Jesus, A. M. P. 2012. An assessment of a strain-life approach for fatigue crack growth, International Journal Structural Integrity 3: 344-376. https://doi.org/10.1108/17579861211281173

Jorge, R. N.; Ribeiro, A.; Jesus, A.; Figueiredo, M.; Castro, P. T.; Fernandes, A. A. 2006. Ponte Eiffel - Viana do Castelo, 
Avaliação de resultados de programa experimental, IDMEC/ FEUP (in Portuguese).

Lesiuk, G. 2013. Microstructural and mechanical degradation of 19th puddled steel: $\mathrm{PhD}$ thesis. Wroclaw University of Technology.

Lesiuk, G.; Szata, M.; Bocian, M. 2015. The mechanical properties and the microstructural degradation effect in an old low carbon steels after 100-years operating time, Archives of Civil and Mechanical Engineering 15: 786-797.

https://doi.org/10.1016/j.acme.2015.06.004

NP EN 10002-1: Materiais metálicos: ensaio de tracção: parte 1 método de ensaio (à temperatura ambiente). Instituto Português da Qualidade, Lisboa, Portugal, 1990 (in Portuguese).

NP EN 10045-1: materiais metálicos: ensaio de choque em provete entalhado Charpy: $1^{a}$ parte - método de ensaio. Instituto Português da Qualidade, Lisboa, Portugal, 1990 (in Portuguese).

Ohga, M.; Appuhamy, J. M. R. S.; Kaita, T.; Fujii, K.; Dissanayake, P. B. R. 2010. Numerical study on remaining strength prediction of corroded steel bridge plates, in International Conference on Sustainable Built Environments (ICSBE-2010), 13-14 December 2010, Kandy, 529-536.
Raposo, P.; Duda, M.; Lesiuk, G.; Correia, J. A. F. O.; Valente, I.; Jesus, A. M. P.; Calçadaa, R. 2017. Structural degradation of puddle irons and steels from old riveted metallic structures, in XI Congresso de Construção Metálica e Mista, Coimbra, Portugal.

Sanches, R. F.; Jesus, A. M. P. D.; Correia, J. A. F. O.; Silva, A. L. L. D.; Fernandes, A. A. 2015. A probabilistic fatigue approach for riveted joints using Monte Carlo simulation, Journal of Constructional Steel Research 110: 149-162. https://doi.org/10.1016/j.jcsr.2015.02.019

Shinae, J.; Jian, L.; Billie, F.; Spencer, J. 2013. Corrosion estimation of a historic Truss Bridge using model updating, Journal of Bridge Engineering 18: 678-689. https://doi.org/10.1061/(ASCE)BE.1943-5592.0000403

Silva, A. L. L. D. 2009a. Comportamento à fadiga de um material de uma ponte metálica centenária sob carrega-mentos complexos (Portuguese): MSc. Dissertation. University of Trásos-Montes and Alto Douro.

Silva, A. L. L. D. 2009b. Comportamento à fadiga de um material de uma ponte metálica centenária sob carregamentos complexos: Master thesis. Universidade de Trás-os-Montes e Alto Douro.

Patrícia RAPOSO born 1991 in Azores, Portugal, is PhD candidate in Faculty of Engineering, University of Porto since September 2017. She is also Research Assistant of Optics and Experimental Mechanics Laboratory (LOME) of INEGI/UP and CONSTRUCT/ FEUP (Portugal). She obtained the MSc in Civil Engineering (structures) by Faculty of Engineering, University of Porto in 2016. Currently, her works in field of the Fatigue and Fracture Mechanics of old riveted steel bridges.

José CORREIA, born 1984 in Peso da Régua, Portugal, is Senior Researcher of Optics and Experimental Mechanics Laboratory (LOME) of INEGI/UP and CONSTRUCT/FEUP (Portugal). He is also Invited Professor at the structural mechanics section in the Civil Engineering Department of the University of Coimbra. He obtained the degrees BSc (2007) and MSc (2009) in Civil Engineering by the University of Trás-os-Montes e Alto Douro. He is specialist in steel and composite (steel and concrete) construction by the University of Coimbra in 2010. He is $\mathrm{PhD}$ in Civil Engineering by University of Porto in 2015. He is also co-author of more 30 papers in the most relevant scientific journals devoted to engineering materials and structures and 80 proceedings in international and national conferences, congresses and workshops. His is an expert in structural integrity, fatigue and fracture of materials and structures.

Grzegorz LESIUK is a lecturer in the Department of Mechanics, Materials Science and Engineering, Faculty of Mechanical Engineering at the Wrocław University of Science and Technology. The research field of dr Lesiuk is connected with the microstructural degradation processes and its potential influence on the mechanical properties of long term operated steel structural members. Another important part of research is fracture mechanics and fatigue fracture in terms of energy methods. During the last four years dr Lesiuk extensively cooperate with Polish and European companies in R+D, Energy, automotive and railway sector. Dr Lesiuk at Wroclaw University of Science and Technology conducts regular lectures and classes: classical mechanics, dynamics, differential equations, fracture mechanics. He is invited as a guest lecturer to The Witelon State University of Applied Sciences in Legnica, Poland (lectures in: Fracture Mechanics, Lightweight Structures, Engineering Failure Analysis). Dr Lesiuk is a member of Polish Group of Fracture Mechanics.

Isabel B. VALENTE is an Assistant Professor at the Department of Civil Engineering, University of Minho. Between 1997 and 2000 , she worked as structural engineer at AFAssociados, Projectos de Engenharia SA. Her main research interests are: experimental and numerical research on steel structures, steel and concrete composite structures, steel and concrete connections and connections between concrete and FRP materials.

Abílio DE JESUS, born 1973 in Oliveira de Azeméis, Portugal, is an expert in Structural Integrity, Fatigue and Mechanical Testing. He obtained his Mechanical Engineering degree at Faculty of Engineering of the University of Porto (FEUP) in 1996, an MSc degree in 1999, and a PhD of University of Trás-os-Montes e Alto Douro in 2004. Currently he is a professor of the Department of Mechanical Engineering of FEUP. He is also co-author of more 100 papers in the most relevant scientific journals devoted to Engineering Materials and structures and more 200 proceedings in international and national Conferences, congresses and workshops. He has been a coordinator or researcher in several international (EU) and national projects (FCT and QREN).

Rui CALÇADA obtained the MSc in Civil Engineering Structures at Faculty of Engineering of the University of Porto (FEUP) in 1996 and the PhD in Civil Engineering at University of Porto in 2003. He is Full Professor at the Civil Engineering Department and Coordinator of the Centre of Competence in Railways of FEUP. He was principal investigator of 12 research projects and was member of the team of 10 research projects in the field of railways. His main research interests are: advanced models for traininfrastructure dynamic interaction; wayside (track, bridges, and transition zones) and on-board condition monitoring systems; advanced algorithms for RCM systems. He is member of the editorial board of the International Journal of Railway Technology. $\mathrm{He}$ is director of the $\mathrm{PhD}$ programme - iRail - Innovation in railway systems and technologies. 